\section{A Monogenic Recessive Gene, $f w$, Conditions Flower Doubling in Nicotiana alata}

\author{
Rozlaily Zainol ${ }^{1}$ and Dennis P. Stimart ${ }^{2}$ \\ Department of Horticulture, University of Wisconsin, 1575 Linden Drive, \\ Madison, WI 53706 \\ Additional index words. breeding, double-flowers, genetics, ornamental tobacco
}

\begin{abstract}
A double-flower form of Nicotiana alata Link \& Otto was characterized genetically as a monogenic recessive trait expressed when homozygous. Reciprocal crosses demonstrated no maternal effect on expression of double flowers. A single dominant gene expressed in the homozygous or heterozygous state caused the singleflower phenotype. The symbol $f w$ is proposed to describe the gene controlling doubleflower phenotype.
\end{abstract}

Nicotiana alata Link \& Otto (Solanaceae), known as 'Jasmine tobacco', is a flowering ornamental tobacco native to tropical northeastern Argentina and southern Brazil (Griffiths, 1994). Plants average $1.5 \mathrm{~m}$ in height with sticky, hairy stalks, ovate to lanceolate leaves, and 5- to 8-cm long trumpet-shaped flowers with pale purple or white interiors, and yellowish exteriors (Graft, 1980; Kohlein and Menzel, 1994). Crosses of $N$. alata $\times$ N.forgetiana Sander ex Hemsl. produce hybrids with white, greenish, pink, and red flowers (Kohlein and Menzel, 1994) commonly used as bedding plants.

A white, double-flowered form of $N$. alata was found in an $\mathrm{F}_{2}$ population of single, white flowering plants (Fig. 1). Anatomical analysis of flowers revealed petal-like outgrowths arising from the anther, connective and filament tissues (Zainol et al., 1998). Petal-like outgrowths can create unique flower types to enhance desirable floral qualities for ornamental use.

Occurrence of flower-doubling has been reported in several solanaceous species, including $N$. langsdorffii J.A. Weinm. hybrids (White, 1914), N. tabacum L. (Hitier, 1950; Komari, 1990) and Petunia $\times$ hybrida Hort. (Saunders, 1910; Scott, 1937). In N. tabacum and $P$. $\times$ hybrida, flower doubling has been reported to be conditioned by single genes, either recessive (Hitier, 1950; Saunders, 1910) or dominant (Hitier, 1950, Natarella and Sink 1971; Scott, 1937; Sink, 1973). Herein, we report on the inheritance of the doubleflowering phenotype in $N$. alata.

Received for publication 23 Nov. 1999. Accepted for publication 5 May 2000.Use of trade names does not imply endorsement of the products named nor criticism of similar ones not named. The cost of publishing this paper was defrayed in part by the payment of page charges. Under postal regulations, this paper therefore must be hereby marked advertisement solely to indicate this fact.

${ }^{1}$ Graduate Research Assistant.

${ }^{2}$ Professor. To whom requests for reprints should be addressed. E-mail address: dstimart@facstaff. wisc.edu

Fig. 1. Double-flowering phenotype of Nicotiana alata 'White' were categorized as normal and double flowers as possessing petal-like outgrowths on anthers and/or filaments (Table 1). Evaluation was conducted in Sept. 1994 (fall) and repeated with a different subsample of seed from the original cross populations in Jan. 1995 (winter). Data were subjected to chisquare analysis using Yates correction term for small populations (Strickberger, 1976).

\section{Results}

Self-pollinated NA produced all doubleflowered progeny and self-pollinated singleflowered DS and ML produced all singleflowered progeny (Table 1). Reciprocal matings of DS or ML $\times$ NA produced singleflowered progeny. The $\mathrm{F}_{2}$ generations, derived from DS or ML x NA, fit a 3 single : 1 double segregation ratio when grown in the fall (Table 1) and were close to a 3:1 ratio when grown in winter. Progeny from backcrosses of the $F_{1}$ generations to $\mathrm{NA}\left(\mathrm{BC}_{\mathrm{Pl}}\right)$ segregated 1:1 in the fall, but one backcross failed to fit the expected 1:1 segregation in the winter. $F_{1}$ plants backcrossed to $\mathrm{ML}\left(\mathrm{BC}_{\mathrm{P} 2}\right)$ produced singleflowers in both seasons. Intercrosses of $F_{1}$ plants (double cross) fit 3:1 segregations except when ML was present in both parents of the intercross grown in winter. Self-pollinations of single- and double-flowered selections derived from multiple cross matings fit 1:1 or 0:1 segregations (Table 2). Backcrosses of single-flowered selections to NA fit 1:1 segregations (Table 2).

Generally, plants exhibited reduced expression of flower-doubling in the winter. Also, expressivity varied between lines but was similar within a line (data not collected). Additionally, a degree of doubling stronger than the parent was observed in some lines among the first generation plants of selfpollinated NA. Flowers on these plants were

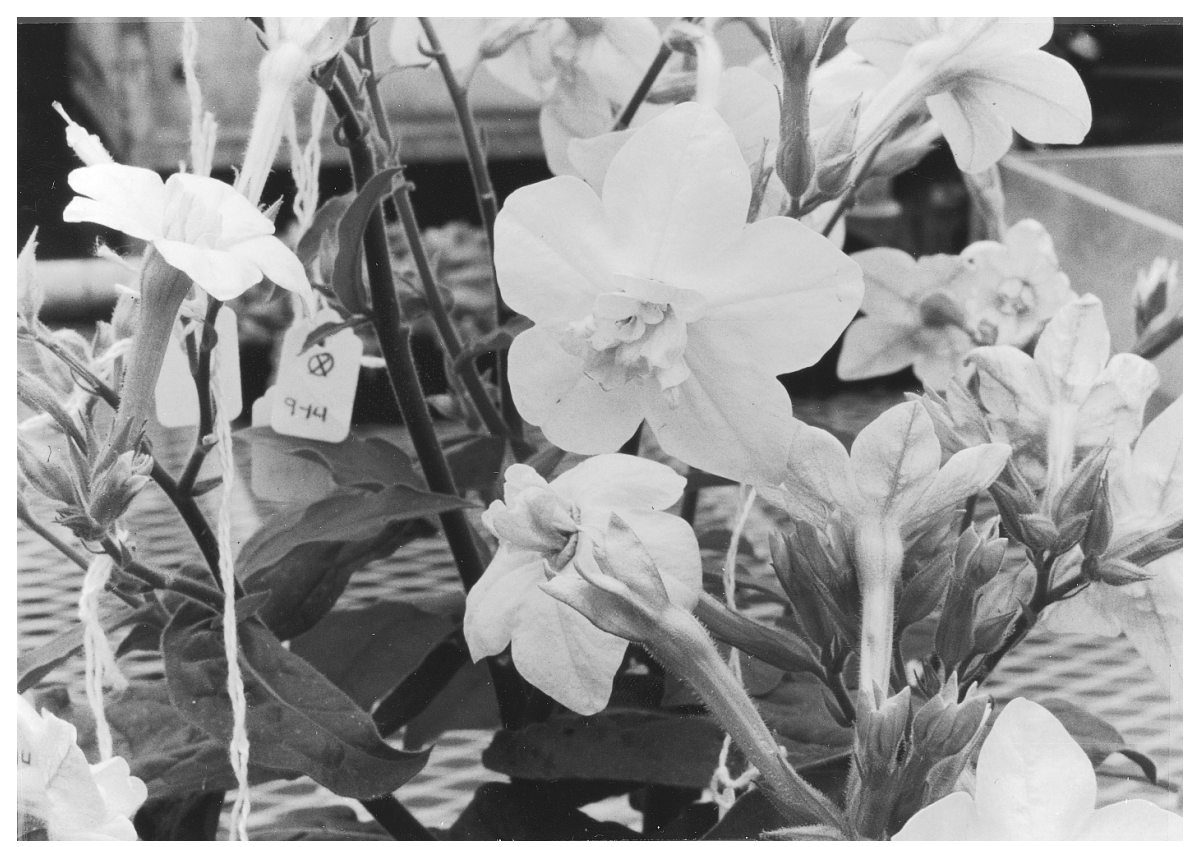


Table 1. Segregation for double-flower form in matings of N. alata Link \& Otto.

\begin{tabular}{|c|c|c|c|c|c|c|c|c|c|}
\hline \multirow[b]{2}{*}{$\underline{\text { Parents/Generation }}$} & \multirow{2}{*}{$\begin{array}{c}\begin{array}{c}\text { Test } \\
\text { ratio }^{z}\end{array} \\
-:+\end{array}$} & \multicolumn{4}{|c|}{$\begin{array}{c}\text { Fall } 1994 \\
\text { Flower form }\end{array}$} & \multicolumn{4}{|c|}{$\begin{array}{l}\text { Winter } 1995 \\
\text { Flower form }\end{array}$} \\
\hline & & - & + & $\chi^{2}$ & $P$ & - & + & $\chi^{2}$ & $P$ \\
\hline \multicolumn{10}{|c|}{ Parents self-pollinated } \\
\hline NA & $0: 1$ & 0 & 27 & All & ouble & 0 & 30 & All s & ingle \\
\hline DS & $1: 0$ & 13 & 0 & All & ingle & 13 & 0 & All s & ingle \\
\hline ML & $1: 0$ & 27 & 0 & All & ingle & 31 & 0 & All s & ingle \\
\hline \multicolumn{10}{|c|}{$F_{1}, F_{2}$, and $B C$} \\
\hline \multicolumn{10}{|l|}{ NA (P1) x DS (P2) } \\
\hline $\mathrm{F}_{1}$ & $1: 0$ & 29 & 0 & All & ingle & 30 & 0 & All s & ingle \\
\hline $\mathrm{F}_{2}$ & $3: 1$ & 19 & 6 & 0.07 & 0.82 & 25 & 6 & 0.39 & 0.55 \\
\hline BCP1 & $1: 1$ & 12 & 15 & 0.46 & 0.50 & 8 & 22 & 6.57 & 0.01 \\
\hline $\mathrm{BCP} 2$ & $1: 0$ & & & --- & --- & & & --- & --- \\
\hline \multicolumn{10}{|c|}{$N A(P 1) \times M L(P 2)$} \\
\hline $\mathrm{F}_{1}$ & $1: 0$ & 28 & 0 & All s & ingle & 34 & 0 & All s & ingle \\
\hline $\mathrm{F}_{2}$ & $3: 1$ & 21 & 7 & 0.05 & 0.85 & 20 & 10 & 1.12 & 0.29 \\
\hline BCP1 & $1: 1$ & 13 & 13 & 0.04 & 0.87 & 19 & 16 & 0.31 & 0.59 \\
\hline $\mathrm{BCP} 2$ & $1: 0$ & 28 & 0 & All & ingle & 30 & 0 & All s & ingle \\
\hline \multicolumn{10}{|c|}{ Reciprocal } \\
\hline $\mathrm{DS} \times \mathrm{NA}$ & $1: 0$ & \multicolumn{2}{|c|}{ No seed } & --- & --- & \multicolumn{2}{|c|}{ No seed } & --- & --- \\
\hline ML $\times$ NA & $1: 0$ & 28 & 0 & All s & ingle & 31 & 0 & All s & ingle \\
\hline \multicolumn{10}{|c|}{ Double cross } \\
\hline$(\mathrm{NA} \times \mathrm{DS}) \times(\mathrm{NA} \times \mathrm{DS})$ & $3: 1$ & 20 & 7 & 0.14 & 0.71 & 22 & 5 & 0.90 & 0.36 \\
\hline$(\mathrm{NA} \times \mathrm{ML}) \times(\mathrm{NA} \times \mathrm{ML})$ & $3: 1$ & 21 & 7 & 0.05 & 0.85 & 29 & 3 & 5.57 & 0.03 \\
\hline$(\mathrm{NA} \times \mathrm{DS}) \times(\mathrm{NA} \times \mathrm{ML})$ & $3: 1$ & 22 & 8 & 0.03 & 0.88 & 21 & 7 & 0.05 & 0.85 \\
\hline
\end{tabular}

${ }^{2} \mathrm{NA}, \mathrm{DS}$, and $\mathrm{ML}=$ N. alata 'White' double-flowered, 'Domino Salmon' single- flowered, and 'Metro Lime' single-flowered, respectively.

${ }^{y}$ Single (-) or double (+) flower form.

Table 2. Segregation for double-flower form in N. alata Link \& Otto after various matings of single- and double-flowered selections in Spring 1996.

\begin{tabular}{|c|c|c|c|c|c|}
\hline \multirow[b]{2}{*}{ Parent $^{z}$} & \multicolumn{2}{|c|}{ Flower form ${ }^{y}$} & \multicolumn{2}{|c|}{ Test ratio } & \multirow[b]{2}{*}{$P$} \\
\hline & - & + & $-:++$ & $\chi^{2}$ & \\
\hline \multicolumn{6}{|c|}{$S_{1}$ of single selections } \\
\hline NA $\times[$ NA $\times($ NA $\times$ DS $)]$ & 25 & 26 & $1: 1$ & 0.02 & 0.89 \\
\hline $\mathrm{NA} \times[\mathrm{NA} \times(\mathrm{NA} \times \mathrm{ML})]$ & 21 & 25 & $1: 1$ & 0.35 & 0.76 \\
\hline \multicolumn{6}{|c|}{$S_{1}$ of double selections } \\
\hline NA "least" double & 0 & 32 & $0: 1$ & All double & \\
\hline NA "most" double & No see & & & & \\
\hline $\mathrm{NA} \times \mathrm{DS}$ & 0 & 14 & $0: 1$ & All double & \\
\hline $\mathrm{NA} \times \mathrm{ML}$ & No see & & & & \\
\hline NA $\times(N A \times D S)$ & 0 & 46 & $0: 1$ & All double & \\
\hline NA $\times($ NA $\times M L)$ & 0 & 50 & $0: 1$ & All double & \\
\hline$(\mathrm{NA} \times \mathrm{DS}) \times(\mathrm{NA} \times \mathrm{DS})$ & 0 & 50 & $0: 1$ & All double & \\
\hline$(\mathrm{NA} \times \mathrm{ML}) \times(\mathrm{NA} \times \mathrm{ML})$ & 0 & 11 & $0: 1$ & All double & \\
\hline$[(\mathrm{NA} \times \mathrm{DS}) \times(\mathrm{NA} \times \mathrm{DS})] \times$ & & & & & \\
\hline$[(\mathrm{NA} \times \mathrm{ML}) \times(\mathrm{NA} \times \mathrm{ML})]$ & 0 & 51 & $0: 1$ & All double & \\
\hline \multicolumn{6}{|c|}{ Single selections $B C_{1}$ to double selections } \\
\hline $\mathrm{NA} \times[\mathrm{NA} \times(\mathrm{NA} \times \mathrm{DS})]$ & 25 & 26 & $1: 1$ & 0.02 & 0.89 \\
\hline $\mathrm{NA} \times[\mathrm{NA} \times(\mathrm{NA} \times \mathrm{ML})]$ & 21 & 25 & $1: 1$ & 0.35 & 0.56 \\
\hline
\end{tabular}

${ }^{2} \mathrm{NA}, \mathrm{DS}$, and ML $=N$. alata 'White' double-flowered, 'Domino Salmon' single-flowered, and 'Metro Lime' single-flowered, respectively.

'Single (-) or double (+) flower form.

deformed slightly, nearly cup-shaped, and yielded no seed because of poor pollen production.

Flowering plants with white, red, salmon, green, or bicolor double corollas were identified among the populations. All color forms expressed strong degrees of doubling.

\section{Discussion}

A nuclear recessive gene conditions the double-flowering phenotype of $N$. alata. The dominant allele conditioned single flowers in either the homozygous or heterozygous state. Segregation data obtained from $F_{1}, F_{2}$, backcross families, and intercrosses between $\mathrm{F}_{1}$
Petal-like outgrowths developed from the filament in progeny of self-pollinated $N$. langsdorffii grandiflora Cav. and in the $\mathrm{F}_{2}$ generation of $N$. langsdorffii $\times N$. forgetiana (White, 1914). Flower doubling in the $\mathrm{F}_{2}$ generation of $N$. langsdorffii $\times N$. alata segregated 35 normal : 15 abnormal (White, 1914). Crosses in our studies of double-flowered by singleflowered plants produced $F_{1}$ progeny of either intermediate doubling or normal flower characteristics. In N. tabacum 'Corolle Double X', flower doubling was controlled by a recessive gene (Hitier, 1950). The origin of this plant remains unknown, but it is believed to have resulted from a cross with $N$. tabacum 'Java Iser' re'. A double-flower form resulting from transformation of $N$. tabacum 'Xanthi' NC was characterized as being controlled by a dominant gene $D f$, homozygous $D f / D f$ or heterozygous $D f /+$.

Flower doubling in Petunia $\times$ hybrida grandiflora was originally determined to be controlled by recessive genes (Saunders, 1910). Later, $P$. Xhybrida flower doubling was attributed to a single dominant gene $D$ (Natarella and Sink 1971; Scott, 1937; Sink, 1973).

In contrast, double flowering response of $N$. alata in the present study was controlled by a monogenic recessive character $f w$. Petal-like outgrowths originated from the androecium, leaving the gynoecium unaffected (Zainol et al., 1998). Also, self-pollinated NA produced progeny with varying degrees of flower doubling originating from the androecium (data not presented), suggesting that minor gene action may be involved in double-flower expression. However, male sterility prevented further investigation into plants with high expression of doubling.

Reynolds and Tampion (1983), reported that plants that produced double flowers were both male- and female-sterile. They stated that when petaloid development from stamens was strong, anthers failed to develop and function normally. Also, the carpel may be affected if petaloidy occurs in the center of the flower as in sterile double-flowering $P$. $\times$ hybrida (Natarella and Sink, 1971). In $N$. alata (Zainol, et al., 1998), it was noted that, as degree of flower doubling increased, the anthers became more deformed and led to increased sterility. In addition, pollen from these plants was largely nonfunctional.

Observed seasonal differences in expressivity of flower doubling suggest that environmental variables influence gene expression, as reported by others (Garrod and Harris, 1974; Kohl, 1961). Transferring the $f w$ gene to lines with other flower colors could increase the ornamental value of $N$. alata. However, challenges to commercial application may exist in the form of monogenic recessive inheritance and sterility factors.

\section{Literature Cited}

propose the symbol $f w$ for the gene controlling the double-flower phenotype in $N$. alata.

In Solanaceae, flower-doubling has been reported in N. langsdorffii (White, 1914), $N$. tabacum (Hitier, 1950; Komari, 1990) and $P$. $\times$ hybrida (Saunders, 1910; Scott, 1937).
Ball, V. 1998. Ball redbook. 16th ed. Ball Publ. Batavia, Ill.

Garrod, J.F. and G.P. Harris. 1974. Studies on the glasshouse carnation: Effects of temperature 
and growth substance on petal number. Ann. Bot. 38:1025-1031.

Graft, A.B. 1980. Tropica. Color encyclopedia of exotic plants and trees, 10th ed. Roehrs, N.J.

Griffiths, M. 1994. Index of garden plants. Timber Press, Portland, Ore.

Hitier, H. 1950. Etude génétique des caractères "enation" et "catacorolle" chez Nicotiana tabacum L. Annales du Tabac 2:31-61. Bergerac (France).

Kohl, H.C. 1961. Period during development of a carnation shoot when temperature has greatest effect on flower size. Proc. Amer. Soc. Hort. Sci. 77:540-543.

Kohlein, F. and P. Menzel. 1994. Color encyclopedia of garden plants and habitats. Timber
Press, Portland, Ore.

Komari, T. 1990. Genetic characterization of a double-flowered tobacco plant obtained in a transformation experiment. Theor. Appl. Genet. 80:167-171

Natarella, N.J. and K.C. Sink. 1971. The morphogenesis of double flowering in Petunia hybrida Hort. J. Amer. Soc. Hort. Sci. 96:600-602.

Reynolds, J. and J. Tampion. 1983. Double flowers: A scientific study. Scientific and Academic Ed. New York.

Saunders, E.R. 1910. Studies in the inheritance of doubleness in flowers. I. Petunia. J. Genet. 1:5759.

Scott, G.W. 1937. A genetical and cytological study of Petunia with special reference to the inherit- ance of doubleness. PhD Diss., Univ. of Calif., Davis.

Sink, K.C. 1973. The inheritance of apetalous flower type in Petunia hybrida Vilm. and linkage tests with the genes for flower doubleness and grandiflora characters and its use in hybrid seed production. Euphytica 22:520-526.

Strickberger, M.W. 1976. Genetics. Macmillan, New York.

White, O.E. 1914. Studies of teratological phenomena in their relation to evaluation and the problems of heredity. Amer. J. Bot. 1:23-36.

Zainol, R., D.P. Stimart, and R.F. Evert. 1998. Anatomical analysis of double flower morphogenesis in Nicotiana alata Link \& Otto. J. Amer. Soc. Hort. Sci. 123:967-972. 